\section{Competing at the top level with Crohn's disease}

\author{
Alyx Treasure
}

\section{EARLY POTENTIAL AND REALISATION OF OLYMPIC DREAMS}

By the time I was 17 , I had already spent 2 years going in/out of hospital. Having been told at the age of 9 that I would make the Olympics, I was very focused on my sporting goals. I had no prior family history of Crohn's. It took 2 years for me to get a diagnosis and this severely affected my athletic development by preventing me from training/competing. I lost my opportunity to go to college in the USA, which had been a long-term ambition, and it would have been easy to give up on the sport.

Fortunately, I didn't give up. I achieved my ultimate goal to qualify for the Canadian Olympic team in the high jump. I jumped 1.94 metres in the qualifying round, which put me in the Olympic final and helped me to realise my lifelong dream aged 24 years.

\section{HEALTH VERSUS SPORTING GOALS}

When you're told at 9 years old that you will make the Olympics you become driven, I would remove anything in my path to achieve my target. I was told several times that I had to quit athletics due to my condition, and one doctor advised me to 'pick health or sport'. I didn't do well with being told what I could or could not do, and over the years, I have argued with my medical team. However, I needed to be challenged and it is great when you can have open and honest discussions with clinicians. I have valued most those clinicians who can advocate on my behalf with the rest of the medical team and help to explain what I am going through.

\section{'MY CROHN'S, MY SYMPTOMS'}

My symptoms are not gastrointestinally driven, and instead, I develop pain and discomfort, which limits my ability to perform. It isn't about what I eat. It has been difficult to find a balance during my career and I am still fighting it. I am not sure that I have it remotely figured out.

We are told by the dieticians and the nutritionists that look after us that we need to eat 'hard to digest foods that

Prince George, British Columbia, Canada

Correspondence to Alyx Treasure, Prince George, BC, Canada; alyx_treasure@hotmail.com support athletics' (such as complex carbohydrates, vegetables and high-fibre foods). Unfortunately, these don't work well for me and I have found that I have to use meal replacements to ensure I have enough energy for training. Luckily, I can tolerate protein, which supports my recovery. I have trained in a semi-fasted state, but hitting peak levels for sustained periods is tough when we are doing a 4-5 hours training session.

\section{OPTIMISING THE CARE OF MY CONDITION}

I find it hard talking with those both inside and outside the sporting environment about diet. It is difficult to find people with an insight into the disease who can empathise. I have learnt that there is no one-time fix and no gastroenterologist, nutritionist or doctor who can help me.

The biggest factor on which I focus on is my preparation. I dedicate months to the maintenance of consistent behaviours, which add up to success. These include optimising my eating, sleep, medication, physio and training. Consistency is hard with Crohn's and I have to fight bad periods to train my body as best as I can, to perform when the time is right.

\section{ATHLETICS IN THE \#METOO ERA}

I had to tell people that I wasn't faking it with my symptoms, and as a young female athlete, I learnt to be assertive. Athletics is cutthroat. I made it, but I was hardened through the process. I was told that I had to be 'tougher' to deal with my symptoms and I coped with this, but some athletes may not have responded so well.

Luckily, I had people telling me positive things about my performance, which helped to balance me out and I was able to respond to those who challenged me. I think the key is supporting athletes to become self-aware about what works for them, and then taking an individualised approach to help them recognise what drives them and how to maximise their medical management alongside their performance.

BECOMING AN ADVOCATE FOR OTHERS I struggled being diagnosed at 17 years old, and I imagine that it would be worse being diagnosed aged 13 or 14 years as you are going through a lot of changes at the same time. I wanted to become an advocate for others with Crohn's disease. I had nobody to look up to and learn from, and having a role model who demonstrates that you can reach the top level in the sport with Crohn's is important. I became a spokesperson for Crohn's Canada, and I am pleased to be able to share my experiences to help others (figure 1 ).

We are in a better place now that Crohn's and other gastric concerns are being researched, and there are medications and treatment plans available.

\section{FUTURE HOPES AND GOALS}

I achieved my initial life goal aged 24 years. It took 2 years for me to re-focus, but I want to break the Canadian high jump record $(1.98 \mathrm{~m}$ at the time of writing) and qualify for Tokyo 2020. I will then be 28 years old and I will consider retirement as I cannot continue to put the same pressure on my body. I am studying business and sustainable fashion so that I have a career beyond athletics, and I am looking forward to living a 'normal' life.

Three pieces of advice for a clinician working with an athlete with Crohn's disease:

1. Communication-I have a great team at Athletics Canada who offer a holistic overview, but I think we need more integrated communication within teams to stop different professions working in silo's. Having the physiotherapists work closer with support staff, such as dieticians, would really support the athletes to reach their peak condition.

2. Holistic understanding of symptomsThe complexity of symptoms that arise from Crohn's and their ability to arise outside of GI-specific complaints means we need to take a whole-body approach. Alteration in eating habits and energy output, increased fatigue or chronic pain, all need to be reviewed for how these symptoms interact with GI concerns. The complexity of symptoms and how they are inter-

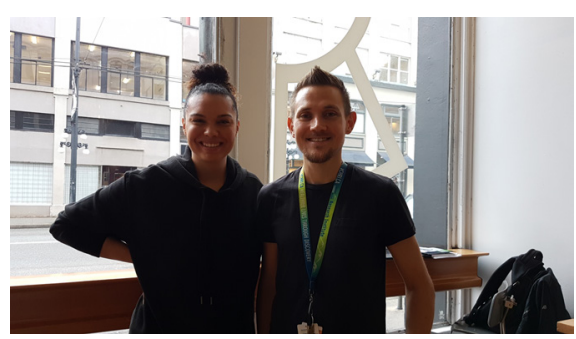

Figure 1 Alyx Treasure pictured left with BJSM Associate Editor Paul Blazey. 


\section{Patient voices}

related should have a greater focus in terms of the relationship between patient and clinician.

3. Individualised approach-Crohn's is a difficult disease to manage as it manifests differently in each patient. Worse than that, it seems to mutate and change over time so you feel that you can never fully understand it. This makes it incredibly difficult to have productive conversations with clinicians on what is happening and why. This is why a long-term individualised program that is monitored closely by the medical team (and more importantly by the patient) is essential. You are your own best advocate and if you can't get a grasp on how your body responds, it is near impossible to make positive impacts on your management of the disease.

Alyx is an ambassador for Crohn's and Colitis Canada who can be found at the following web address-http://crohnsandcolitis.ca/ or via social media @ getgutsycanada.

Contributors This work was written up by Paul Blazey-Associate Editor with BJSM following an in-person interview conducted with the athlete in focus, AT.

Funding The authors have not declared a specific grant for this research from any funding agency in the public, commercial or not-for-profit sectors.
Competing interests None declared.

Patient consent for publication Obtained.

Provenance and peer review Commissioned; internally peer reviewed.

(c) Author(s) (or their employer(s)) 2020. No commercial re-use. See rights and permissions. Published by BMJ.

- Additional material is published online only. To view, please visit the journal online (http://dx.doi.org/ 10.1136/bjsports-2019-100807).

\section{(A) Check for updates}

To cite Treasure A. Br J Sports Med 2020;54:365-366.

Accepted 2 June 2019

Published Online First 5 July 2019

Br J Sports Med 2020;54:365-366. doi:10.1136/bjsports-2019-100807 